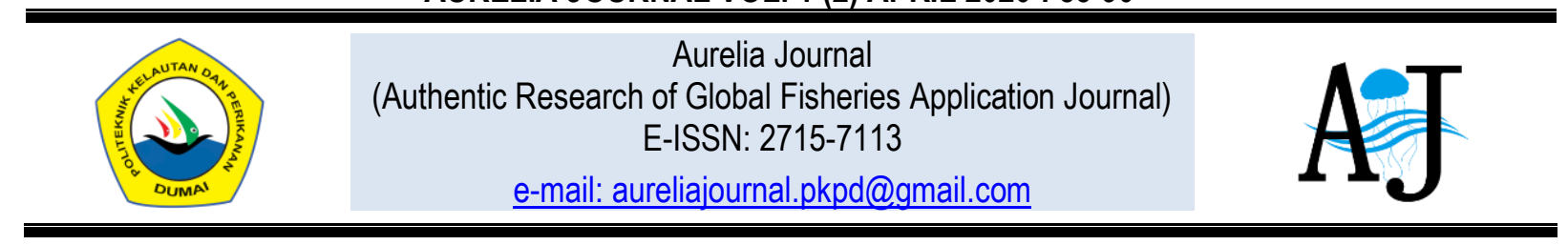

\title{
STUDI KELAYAKAN LOKASI BARANG MUATAN KAPAL TENGGELAM (BMKT) SEBAGAI WISATA SELAM DI KABUPATEN KARAWANG JAWA BARAT
}

\section{FEASIBILITY STUDY OF ESTABLISHING SHIPWRECK LOCATION AS DIVE TOURISM IN KARAWANG DISTRICT WEST JAVA}

\author{
Perdana Putra Kelana ${ }^{1,2^{\star}}$, Sandra Moerti Oktavian², Muhammad Fiqi Fadillah²,3, \\ Muhammad Nur Arkham ${ }^{1}$ \\ 'Dosen Politeknik Kelautan dan Perikanan Dumai \\ ${ }^{2}$ Anggota Parimanta FPIK Universitas Padjadjaran \\ ${ }_{3}^{3}$ Mahasiswa Pasca Sarjana Universitas Pertahanan Program Studi Teknologi Penginderaan \\ *Korespondensi: perdana.pk@politeknikkpdumai.ac.id (Perdana PK) \\ Diterima 25 Februari 2020 - Disetujui 31 Maret 2020
}

\begin{abstract}
ABSTRAK. Benda Muatan Kapal Tenggelam (BMKT) dapat dimanfaatkan sebagai wisata selam. Kabupaten Karawang memiliki 3 lokasi BMKT yang akan dimanfaatkan untuk wisata selam. Studi ini dilakukan pada bulan Oktober 2019 dengan mengamati 4 stasiun pengambilan data yaitu Karang Kapalan, Karang Sendulang dan Karang Tamiyang serta Pulau Gede. Metode yang digunakan dalam studi ini adalah metode survey. Adapun parameter yang diamati adalah jarak lokasi dari pantai, kondisi BMKT, dan kecerahan perairan serta kecepatan arus. Pengolahan data dilakukan untuk menghitung nilai Indeks Kelayakan Wisata (IKW) guna mengetahui kategori kelayakan wisata. Berdasarkan hasil studi, BMKT yang berupa fragmen keramik dalam kondisi tidak utuh dan keceraha perairan yang rendah menjadi penyebab nilai IKW rendah. Nilai IKW ke-4 stasiun berada pada kisaran $39-41 \%$ dan termasuk kedalam kategori sesuai bersyarat.
\end{abstract}

KATA KUNCI: BMKT, Karawang, kelayakan, selam, wisata

ABSTRACT. Shipwreck can be used as diving tourism. Karawang Regency has 3 Shipwreck locations that will be used for diving tourism. This study was conducted in October 2019 by observing 4 stations, Karang Kapalan, Sendulang, Karang Tamiyang and Gede Island. survey method used in this study. The parameters observed were distance from the coast, Shipwreck conditions, waters brightness and current speed. Data processing performed to calculate the value of the Tourism Feasibility Index in order to determine the category of tourism feasibility. Based on the results of the study, Shipwreck found in the form of ceramic fragments in incomplete conditions and low water brightness caused low Tourism Feasibility Index values. The Tourism Feasibility Index value for the 4 stations was in the range of $39-41 \%$, that was means Shipwreck had some condition as diving tourism.

KEY WORDS: Shipwreck, Karawang, feasibility, dive, tourism

\section{Pendahuluan}

Indonesai merupakan negara maritim yang memiliki arkeologi bawah air sebagai potensi warisan budaya bawah laut (Underwater Cultural Heritage), hal tersebut diiringi dengan tantangan pengelolaan pelestarianya (Carducci, 2002). Benda Muatan Kapal Tenggelam (BMKT) merupakan salah satu contoh dari arkeologi bawah air. BMKT adalah benda berharga yang memiliki nilai sejarah, budaya, ilmu pengetahuan, dan ekonomi yang tenggelam di wilayah perairan Indonesia ZEE, dan Landas kontinen Indoensia, paling singkat berumur 50 tahun (Keputusan Presiden No. 19 Tahun 2007 tentang Panitia Nasional Pengangkatan dan Pemanfaatan Benda Berharga Asal Muatan Kapal yag Tenggelam). 
Kabupaten Karawang memiliki 3 lokasi BMKT yaitu Karang Kapalan, Karang Sendulang dan Karang Tamiyang yang masuk kedalam Kawasan Konservasi (KK) pada subzona Kawasan Konservasi Maritim (KKM) (Peraturan Daerah Provinsi Jawa Barat No. 5 Tahun 2019 tentang Rencana Zonasi Pesisir dan Puau-Pulau Kecil Provinsi Jawa Barat Tahun 2019-2023). BMKT masuk kedalam KKM dikarenakan KKM dapat mencakup daerah perlindungan adat maritim dan daerah perlindungan budaya maritim. Daerah perlindungan budaya maritim ditetapkan dengan kriteria lokasi kapal tenggelam yang mempunyai nilai ekonomi, sejarah, budaya, dan atau ilmu pengetahuan, situs sejarah kemaritiman yang mempunyai nilai penting bagi sejarah, ilmu pengetahuan, dan budaya yang perlu dilindungi bagi tujuan pelestarian dan pemanfaatan guna memajukan kebudayaan nasional dan tempat upacara keagamaan atau adat (Peraturan Pemerintah Republik Indonesia No. 32 Tahun 2019 tentang Rencana Tata Ruang Laut). Salah satu pemanfaatan BMKT yang dapat dilakukan adalah wisata minat khusus yaitu wisata selam.

Tiga lokasi BMKT di Kabupaten Karawang memiliki daya tarik tersendiri bagi para wisatawan untuk menyelam, khususnya untuk meilhat ataupun mempelajari mengenai BMKT yang terdapat di wilayah tersebut. Lokasi menyelam yang baik juga ditentukan oleh kondisi perairan. Pemerintah provinsi maupun kabupaten berencana untuk melakukan pengelolaan wilayah tersebut menjadi daerah tujuan wisata selam. Berdasarkan hal tersebut, maka perlu dilakukan studi mengenai kelayakan lokasi BMKT sebagai wisata selam di Kabupaten Karawang, Jawa Barat.

\section{Bahan dan Metode}

\subsection{Waktu dan Tempat Studi}

Studi ini dilakukan selama bulan Oktober 2019 bertempat di Kabupaten Karawang, Jawa Barat. Adapun lokasi pengambilan data dilakukan pada 4 stasiun yaitu Karang Kapalan (Stasiun 1), Karang Sendulang (Stasiun 2) dan Karang Tamiyang (stasiun 3) serta Pulau Gede (Stasiun 4). Lokasi pengambilan data secara detail tersaji pada Gambar 1 dan Tabel 1.

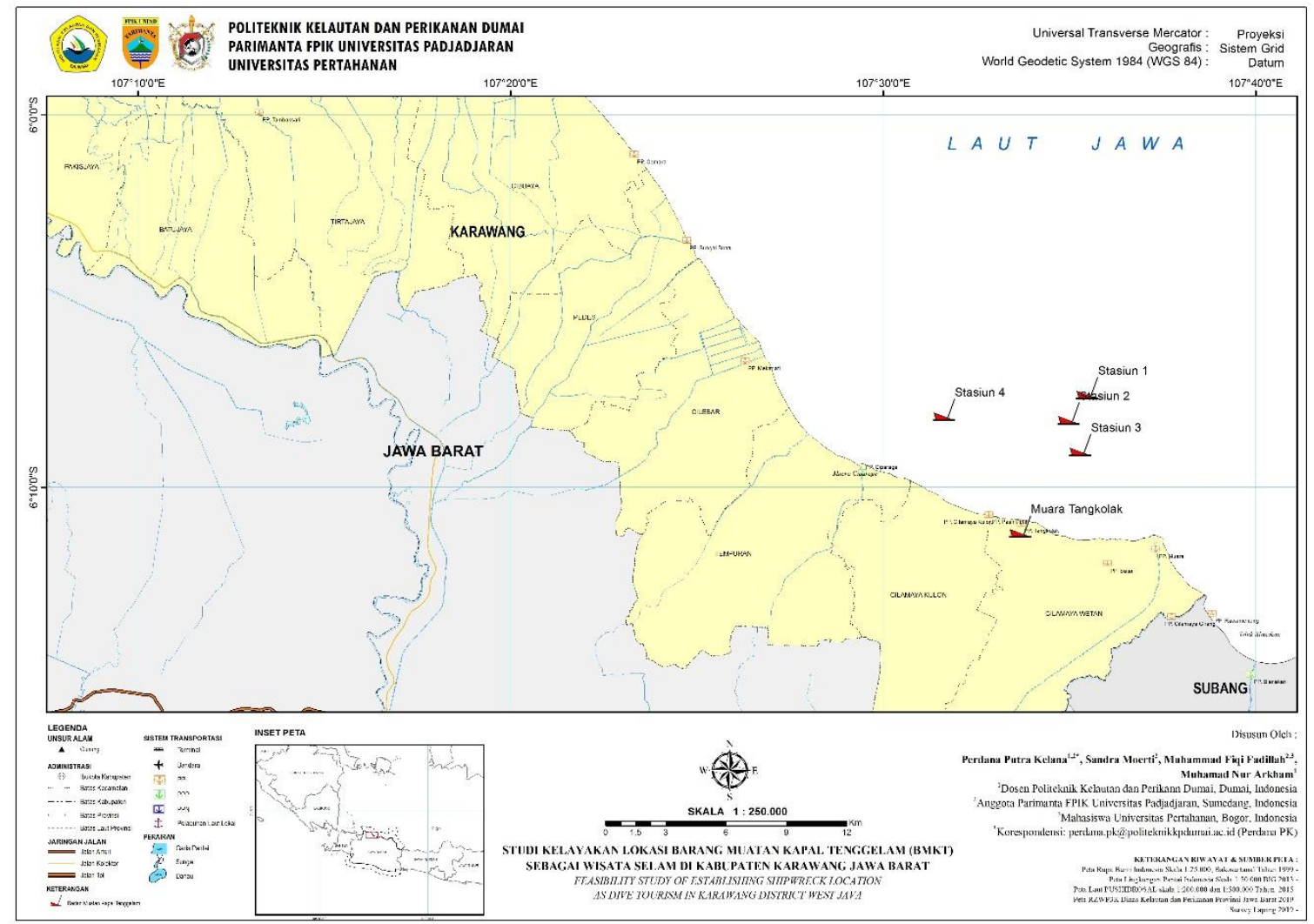

Gambar 1. Peta Lokasi Pengambilan Data 
Tabel 1. Koordinat Lokasi Pengambilan Data

\begin{tabular}{clcc} 
Stasiun & \multicolumn{1}{c}{ Lokasi } & Longitude & Latitude \\
\hline 1 & Karang Kapalan & $107^{\circ} 35^{\prime} 28.5747^{\prime \prime} \mathrm{E}$ & $6^{\circ} 07^{\prime} 21.0622^{\prime \prime} \mathrm{S}$ \\
2 & Karang Sendulang & $107^{\circ} 34^{\prime} 58.6406^{\prime \prime} \mathrm{E}$ & $6^{\circ} 08^{\prime} 02.0369^{\prime \prime} \mathrm{S}$ \\
3 & Karang Tamiyang & $107^{\circ} 35^{\prime} 17.3482^{\prime \prime} \mathrm{E}$ & $6^{\circ} 08^{\prime} 52.7319^{\prime \prime} \mathrm{S}$ \\
4 & Pulau Gede & $107^{\circ} 31^{\prime} 38.0000^{\prime \prime} \mathrm{E}$ & $6^{\circ} 07^{\prime} 55.9129^{\prime \prime} \mathrm{S}$ \\
\hline
\end{tabular}

\subsection{Peralatan studi}

Peralatan yang digunakan untuk mengambil data pada studi ini secara umum terbagi menjadi 3 jenis yaitu alat selam, alat dokumentasi dan alat untuk mengukur kualitas perairan. Adapun peralatan studi cera lengkap terdapat pada Tabel 2.

Tabel 2. Peralatan Pengambilan Data

\begin{tabular}{ll}
\multicolumn{1}{c}{ Alat } & \multicolumn{1}{c}{ Kegunaan } \\
\hline Scuba equipment & Menyelam \\
Roll Meter & Membuat garis transek \\
Underwater camera & Mendokumentasikan kegiatan \\
GPS & Mencatat koordinat \\
Depth gauge & Mengukur Kedalaman \\
Secchi disc & Mengukur Kecerahan \\
Current meter & Mengukur Kecepatan Arus \\
\hline
\end{tabular}

\subsection{Metode pengambilan data}

Data yang digunakan pada studi ini adalah data primer dan sekunder. Metode yang digunakan untuk pengambilan data primer adalah metode survey dengan pendekatan arkeologi bawah air melalui kegiatan penyelaman untuk mengetahui kondisi situs (Ridwan, Kusumah, Husrin, \& Altanto, 2014). Kondisi lingkungan perairan yang diamati secara langsung (insitu) diantaranya adalah kecerahan, kedalaman dan kecepatan arus. Data sekunder merupakan data yang diperoleh dari studi pustaka terhadap artikel ilmiah dengan tema sejenis, laporan kegiatan dilokasi yang sama dan data dari instansi terkait (Sari, Putra, \& Dirgayusa, 2017).

\subsection{Metode pengolahan data}

Data kecerahan perairan diukur menggunakan secchi disc. Hasil pengukuran dilapangan belum menggambarkan nilai kecerahan perairan. Nilai kecerahan perairan didapatkan dengan menggunakan rumus berikut:

$$
I=\frac{\left(\frac{H 1+H 2}{2}\right)}{H \text { total }} \times 100 \%
$$

Dimana:

I : Kecerahan perairan (\%)

$\mathrm{H} 1 \quad$ : Kedalaman secchi disc hingga tak tampak (m)

$\mathrm{H} 2$ : Kedalaman secchi disc ketika tampak (m)

$\mathrm{H}$ total : Kedalaman Perairan $(\mathrm{m})$.

Data yang diperoleh kemudian dianalisis menggunakan matriks kesesuaian lokasi BMKT sebagai wisata selam. Matriks tersebut merupakan modifikasi dari matriks kesesuaian untuk wisata selam dan penilaian faktor potensi tinggalan budaya bawah air seperti pada Tabel 3. Langkah 
selanjutnya adalah menghitung nilai indeks kesesuaian lokasi BMKT sebagai wisata selam menggunakan formula berikut:

Dimana:

$$
I K W=\sum_{i=1}^{n}\left[\frac{N i}{N \max }\right] \times 100 \%
$$

IKW : Indeks Kesesuaian Wisata

$\mathrm{Ni} \quad$ : Nilai parameter ke-i (bobot $\mathrm{x}$ skor)

$\mathrm{N}$ max : Nilai maksimum

Hasil perhitungan indeks kesesuaian wisata tersebut kemudian disesuaikan dengan Tabel $\mathbf{4}$, maka akan terlihat status kesesuaiannya.

Tabel 3. Matriks Kesesuaian Lokasi BMKT Sebagai Wisata Selam

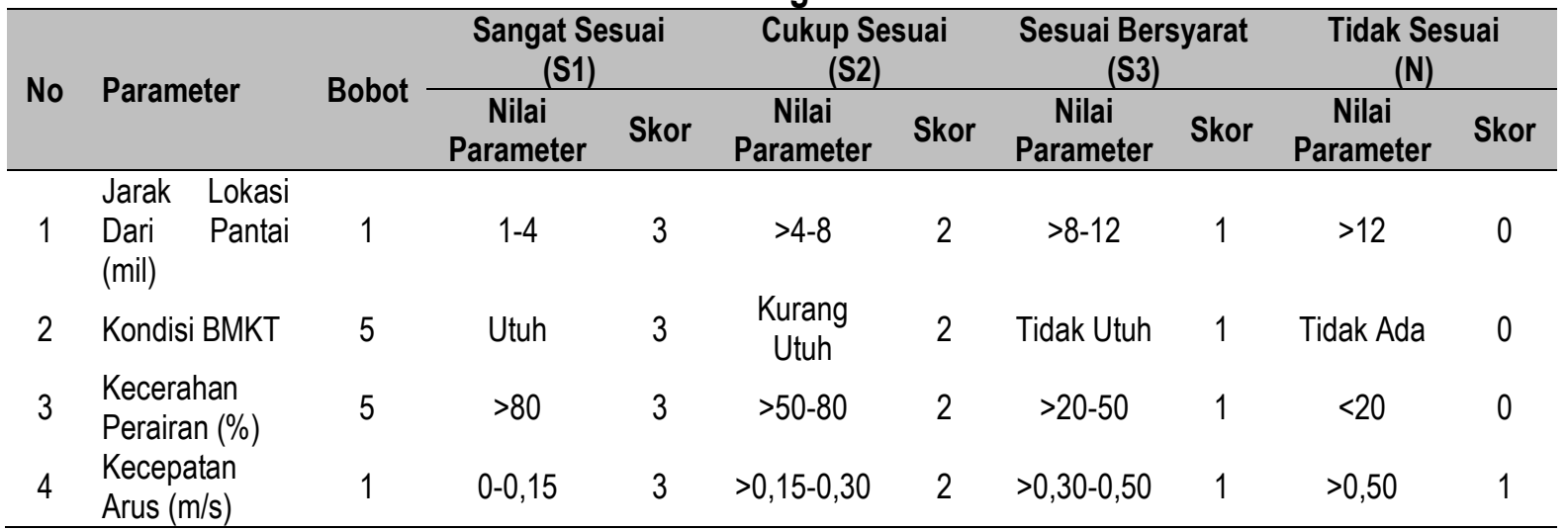

Sumber: (Yulianda, 2007) dalam (Kantona, Adi, \& Kurniawan, 2016) dan (Ardiwidjaja, 2017) (modifikasi)

Tabel 4. Kelas Kesesuaian

\begin{tabular}{lcc} 
& Kategori & Nilai IKW \\
\hline Sangat Sesuai (S1) & $>80-100 \%$ \\
Cukup Sesuiai (S2) & $>60-80 \%$ \\
Sesuai Bersyarat (S3) & $>17-50 \%$ \\
Tidak Sesuai (N) & $>17 \%$ \\
\hline
\end{tabular}

Sumber: (Yulianda, 2007) dalam (Kantona, Adi, \& Kurniawan, 2016)

\section{Hasil dan Pembahasan}

Akses utama dan terdekat menuju lokasi BMKT adalah melalui Muara Tangkolak. Lokasi BMKT terdekat dari Muara Tangkolak adalah stasiun 3 dengan jarak 3,25 mil, sedangkan yang terjauh adalah stasiun 1 dan 4 dengan jarak 4,71 mil (Gambar 2). Jarak tempuh yang terhitung dekat dapat memudahkan pengelolaan wisata selam. Hal tersebut sesuai dengan pernyataan Ardiwidjaja (2017) yang menyebutkan bahwa setiap tinggalan Kapal tenggelam dan muatannya yang berada pada lokasi atau jalur rempah dan sutra dengan kedalaman kurang dari $60 \mathrm{~m}$ dan berjarak di bawah 12 mil dari pantai serta memiliki kondisi perairan yang baik dapat dimanfaatkan untuk kepentingan edukasi, wisata selam dan museum. 


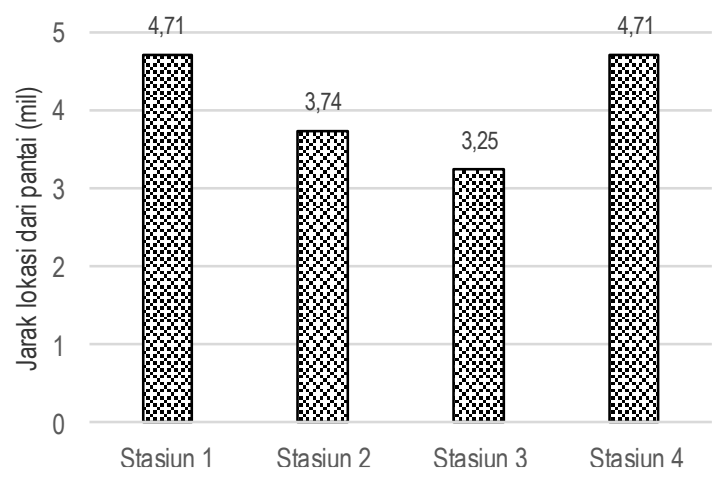

Gambar 2. Jarak Lokasi BMKT dari Pantai

BMKT yang ditemukan di seluruh stasiun pengamatan berupa fragmen keramik (Gambar 3). Fragmen keramik tersebut diduga berasal dari Cina (Loka Riset Sumber Daya dan Kerentanan Pesisir, 2017). BMKT yang terdapat di wilayah perairan Kabupaten Karawang sudah ada yang diangkat dan disimpan di Pusat Informasi Bahari Tangkolak Muara Tangkolak sebagai sarana informasi dan edukasi.

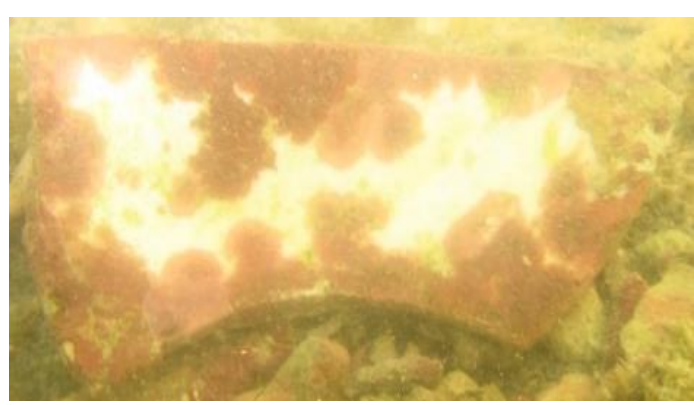

(a)

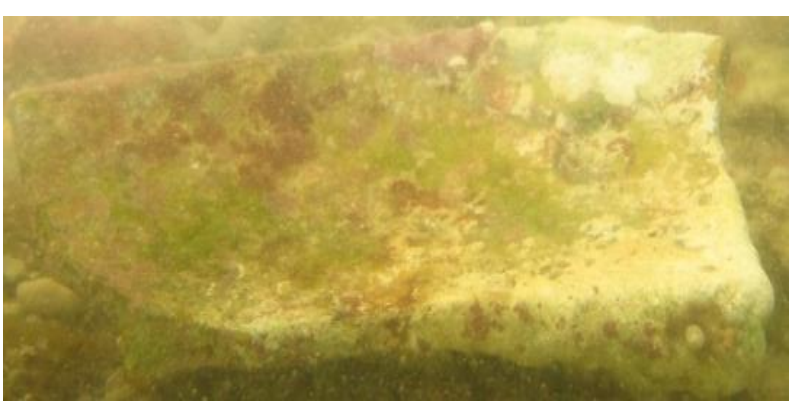

(b)

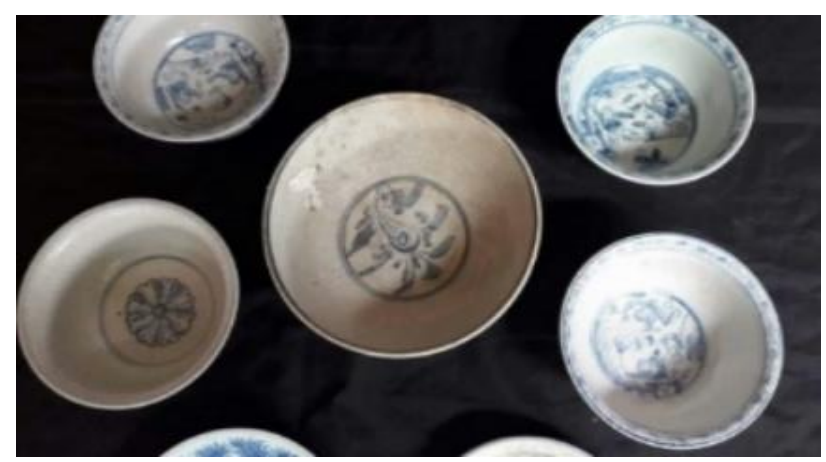

(c)

\section{Gambar 3. (a) dan (b) Potongan BMKT yang ditemukan di 4 Stasiun (C) BMKT di Pusat Informasi Bahari Tangkolak}

Kedalaman merupakan salah satu parameter oceanografi yang harus diperhatikan guna merumuskan kelayakan perairan untuk wisata selam (Sari, Putra, \& Dirgayusa, 2017). Perairan Kabupaten Karawang memiliki kedalaman anatara 0-40 m. Secara Umum Perairan di Wilayah Pantai Utara Jawa Barat memiliki nilai kedalaman 1-2 m, sedangkan pada jarak rata-rata $4 \mathrm{~km}$ (2,3 mil) ke arah laut dari garis pantai memiliki kedalaman 5-10 m, kemudian pada jarak rata-rata $13 \mathrm{~km}$ (7 mil laut) kedalaman berkisar 10-20 m, dan pada jarak $20 \mathrm{~km}$ (>12 mil laut) kedalaman berkisar antara 20-40 m (Dinas Kelautan dan Perikanan Jawa Barat, 2019). Hasil pengukuran kedalaman di lokasi BMKT berkisar antara 3-11 m (Gambar 4). Stasiun 4 memiliki kedalaman terdangkal dengan nilai $3 \mathrm{~m}$ sedangkan stasiun 1 memiliki kedalam terdalam dengan nilai $11 \mathrm{~m}$. 


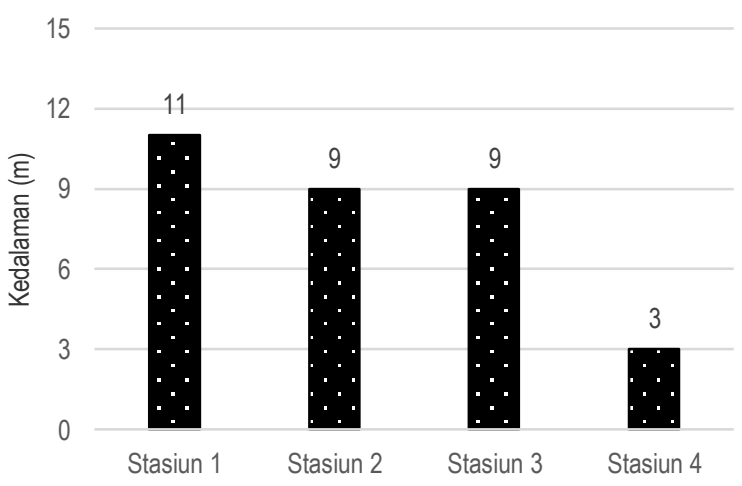

Gambar 4. Kedalaman Lokasi BMKT

Kecerahan air merupakan ukuran kejernihan suatu perairan, semakin tinggi suatu kecerahan perairan semakin dalam cahaya menembus ke dalam air. Kecerahan menggambarkan sejumlah atau sebagian cahaya yang diteruskan pada kedalaman tertentu yang dinyatakan dengan persen (Effendi, 2003). Tingkat kecerahan di wilayah Pantai Utara Jawa Barat termasuk sangat rendah. Hal tersebut dikarenakan substart mengandung lempung dengan butiran yang halus sehingga mudah teraduk dalam kondisi arus kencang yang mengakibatkan kecerahan menjadi rendah (Dinas Kelautan dan Perikanan Jawa Barat, 2019). Hasil pengukuran kecerahan di lokasi BMKT menunjukan bahwa persentase kecerahan termasuk dalam kategori rendah. Nilai terandeh terdapat di stasiun 1 dengan nilai $27 \%$, sedangkan stasiun 2, 3 dan 4 memiliki nilai kecerahan yang sama yaitu $33 \%$. Nilai kecerahan lokasi BMKT tersaji pada Gambar 5.

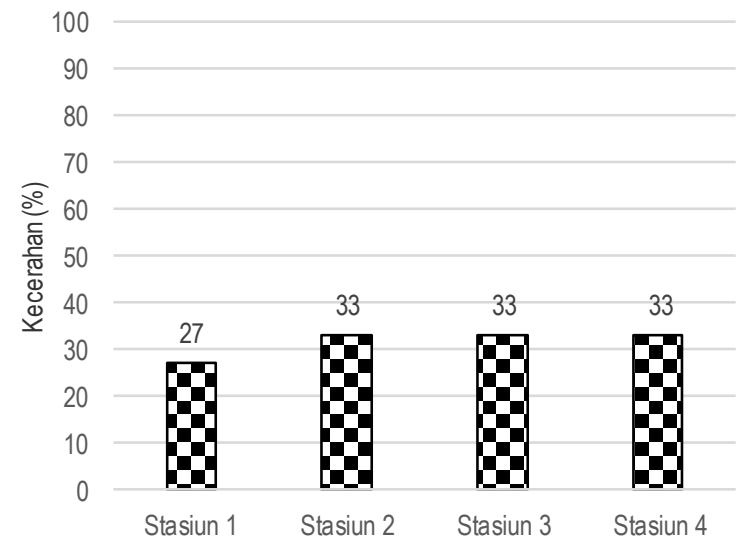

\section{Gambar 5. Persentase Kecerahan Lokasi BMKT}

Arus laut adalah gerakan massa air dari suatu tempat ke tempat yang lain. Arus laut dapat disebabkan oleh angin. Arus juga dipengaruhi oleh musim dan pasang surut (Azis, 2006). Hasil pengukuran arus di lokasi BMKT menunjukan bahwa arus saat pengabilan data berkisar antara 0,16$0,22 \mathrm{~m} / \mathrm{s}$ (Gambar 6). Arus tertinggi terdapat di stasiun 3 dengan kecepatan 0,22 m/s. Arus terendah terdapat di stasiun 4 dengan kecepatan $0,16 \mathrm{~m} / \mathrm{s}$.

Penyelenggaraan wisata khususnya selam memperhatikan 3 aspek yaitu pelayanan, produk dan pengelolaan. Salah satu bentuk dari aspek pelayanan dan pengelolaan diantaranya adalah penyampaian informasi dan sarana prasaran wisata (Kristiningrum \& Isharyadi, 2018). Penyampaian informasi mengenai jarak tempuh dan kondisi sarana prasanaran khususnya kapal yang digunakan untuk samapi lokasi BMKT menjadi bahan pertimbangan bagi wisatawan untuk melakukan wisata selam. Jarak tempuh lokasi BMKT menjadi pertimbangan bagi wisatawan, jarak tempuh yang pendek dapat memangkas waktu tempuh, meskipun dengan armada yang sederhana. Stasiun 1 dan 3 memilki 
jarak tempuh yang masuk dalam kategori skor 3, sedangkan stasiun 1 dan 4 masuk dalam kategori skor 2. Aspek produk pada stasiun penelitian adalah keramik atauun fragmen keramik yang berasala dari Cina. Kondisi BMKT berupa fragment keramik yang ditemukan di seluruh stasiun masuk dalam kategori tidak utuh sehingga hanya memiliki skor 1.

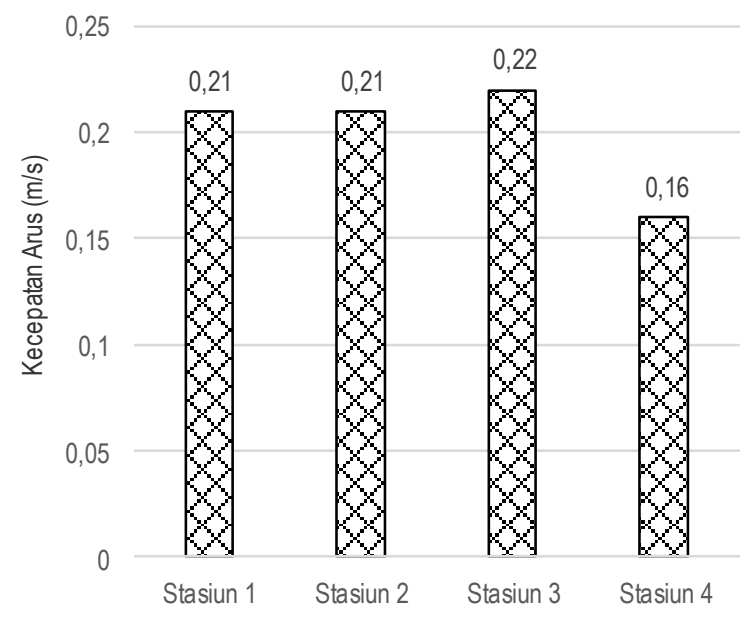

\section{Gambar 6. Kecepatan Arus Lokasi BMKT}

Kecerahan perairan lokasi BMKT di seluruh stasiun memiliki skor 1 karena berada pada kisaran $>20-50 \%$. Kondisi ini terjadi karena pada saat pengambilan data, cuaca cerah namum angin kencang yang mempengaruhi arus membuat substrat yang ada teraduk dan mengakibatkan persentase kecerahan rendah (Rahmawan, et al., 2019). Kecepatan arus pada lokasi penelitian yang berkisar antara 0,16-0,21 m/s memiliki skor 2. Kecepatan arus tersebut masuk dalam kategori cukup baik namun belum optimal untuk wisata selam karena kecepatan arus yang optimal untuk penyelaman adalah $<0,15 \mathrm{~m} / \mathrm{s}$ (Syahputra, Yunasfi, \& Suryanti, 2016). Nilai IKW Lokasi BMKT berada pada kisaran $39-41 \%$ dan seluruh stasiun berada pada kategori S3 atau sesuai bersyarat (Tabel 5). Kondisi BMKT yang hanya berupa fragment keramik masuk kedalam kategori tidak utuh. Hal tersebut berpengaruh besar terhadap nilai IKW. Selain itu, kecerahan perairan yang tergolong rendah juga berdampak langsung pada rendahnya nilai IKW.

Tabel 5. Nilai Parameter, IKW dan Kategori Kesesuaian

\begin{tabular}{|c|c|c|c|c|c|c|c|c|c|c|c|c|c|}
\hline \multirow[b]{2}{*}{ Parameter } & \multirow[b]{2}{*}{ Bobot } & \multicolumn{3}{|c|}{ Stasiun 1} & \multicolumn{3}{|c|}{ Stasiun 2} & \multicolumn{3}{|c|}{ Stasiun 3} & \multicolumn{3}{|c|}{ Stasiun 4} \\
\hline & & Nilai & Skor & $\begin{array}{l}\text { Skor } \\
\text { Akhir }\end{array}$ & Nilai & Skor & $\begin{array}{l}\text { Skor } \\
\text { Akhir }\end{array}$ & Nilai & Skor & $\begin{array}{l}\text { Skor } \\
\text { Akhir }\end{array}$ & Nilai & Skor & $\begin{array}{l}\text { Skor } \\
\text { Akhir }\end{array}$ \\
\hline $\begin{array}{l}\text { Jarak } \\
\text { Lokasi }\end{array}$ & & & & & & & & & & & & & \\
\hline $\begin{array}{l}\text { Dari } \\
\text { Pantai } \\
\text { (mil) }\end{array}$ & 1 & 4,71 & 2 & 2 & 3,74 & 3 & 3 & 3,25 & 3 & 3 & 4,71 & 2 & 2 \\
\hline $\begin{array}{l}\text { Kondisi } \\
\text { BMKT } \\
\text { Kecerahan }\end{array}$ & 5 & $\begin{array}{l}\text { Tidak } \\
\text { Utuh }\end{array}$ & 1 & 5 & $\begin{array}{l}\text { Tidak } \\
\text { Utuh }\end{array}$ & 1 & 5 & $\begin{array}{l}\text { Tidak } \\
\text { Utuh }\end{array}$ & 1 & 5 & $\begin{array}{l}\text { Tidak } \\
\text { Utuh }\end{array}$ & 1 & 5 \\
\hline $\begin{array}{l}\text { Perairan } \\
(\%)\end{array}$ & 5 & 27 & 1 & 5 & 33 & 1 & 5 & 33 & 1 & 5 & 33 & 1 & 5 \\
\hline $\begin{array}{l}\text { Kecepatan } \\
\text { Arus }(\mathrm{m} / \mathrm{s})\end{array}$ & 1 & 0,21 & 2 & 2 & 0,21 & 2 & 2 & 0,22 & 2 & 2 & 0,16 & 2 & 2 \\
\hline & & $\begin{array}{l}\text { Total } \\
\text { IKW } \\
\text { Kateg }\end{array}$ & & $\begin{array}{l}14 \\
39 \% \\
\text { S3 }\end{array}$ & $\begin{array}{l}\text { Total } \\
\text { IKW } \\
\text { Kateg }\end{array}$ & & $\begin{array}{l}15 \\
41 \% \\
\text { S3 }\end{array}$ & $\begin{array}{l}\text { Total } \\
\text { IKW } \\
\text { Kateg }\end{array}$ & & $\begin{array}{l}15 \\
41 \% \\
\text { S3 }\end{array}$ & $\begin{array}{l}\text { Total } \\
\text { IKW } \\
\text { Kateg }\end{array}$ & & $\begin{array}{l}14 \\
39 \% \\
\text { S3 }\end{array}$ \\
\hline
\end{tabular}




\section{Kesimpulan}

Secara umum ke-4 lokasi BMKT yang terdapat di perairan Kabupaten Karawang Jawa Barat dapat dijadikan lokasi selam dengan kategori sesuai bersyarat. Adapun beberapa hal yang dapat dilakukan guna meningkatkan nilai IKW dan minat wisatawan diantaranya adalah dengan melakukan duplikasi BMKT. Selain duplikasi BMKT, pemindahan BMKT dapat menjadi alternatif, seperti pemindahan BMKT dari Karang Bui Kabupaten Subang. Guna menunjang kenyamanan para penyelam, perlu dilakukan studi lanjut untuk mengetahui waktu kecerahan optimum dan daya dukung. Informasi mengenai waktu kecerahan optimum dan daya dukung kawasan akan membantu pengelolaan lokasi BMKT sebagai wisata selam menjadi lebih komperhensif.

\section{Daftar Pustaka}

Ardiwidjaja, R. (2017). Pelestarian Tiggalan Budaya Bawah Air: Pemanfaatan Kapal Karam Sebagai Daya Tarik Wisata Selam. AMERTA, Jurnal Penelitian dan Pengembangan Arkeologi, 35(2), 133-148.

Azis, M. F. (2006). Gerak Air di Laut. Oseana, 31(4), 9-21.

Carducci, G. (2002). New Developments in the Law of the: The UNESCO Convention on the Protection of Underwater Cultural Heritage. American Journal of International Law, 96(2), 419-434. doi:10.2307/2693936

Dinas Kelautan dan Perikanan Jawa Barat. (2019). Buku Data dan Analisis "Kajian Pemanfaatan BMKT Sebagai Lokasi Wisata Bahari". Bandung.

Effendi, H. (2003). Telaah Kualitas Air Bagi Pengelolaan Sumberdaya dan Lingkungan Perairan. Yogyakarta: Kanisius.

Kantona, I., Adi, W., \& Kurniawan. (2016). Potensi Kesesuaian Lokasi Wisata Selam Permukaan (Snorkeling) Sebagai Pengembangan Wisata Bahari Pantai Turun Aban Kabupaten Bangka. Akuatik - Jurnal Sumberdaya Perairan, 10(2), 22-29.

Keputusan Presiden No. 19 Tahun 2007 tentang Panitia Nasional Pengangkatan dan Pemanfaatan Benda Berharga Asal Muatan Kapal yag Tenggelam. (n.d.). Jakarta.

Kristiningrum, E., \& Isharyadi, F. (2018). Pemenuhan Persyaratan Standar Pengelolaan Wisata Selam Rekreasi. Jurnal Standardisasi, 20(1), 33-48.

Loka Riset Sumber Daya dan Kerentanan Pesisir. (2017). Laporan Kegiatan Mini Survey BMKT Karawang - Subang. Jakarta.

Peraturan Daerah Provinsi Jawa Barat No. 5 Tahun 2019 tentang Rencana Zonasi Pesisir dan PuauPulau Kecil Provinsi Jawa Barat Tahun 2019-2023. (n.d.). Bandung: Sekretaris Daerah Provinsi Jawa Barat.

Peraturan Pemerintah Republik Indonesia No. 32 Tahun 2019 tentang Rencana Tata Ruang Laut. (n.d.). Jakarta: Kementerian Hukum dan Hak Azasi Manusia Republik Indonesia.

Rahmawan, G., Wisha, U., Gemilang, W., Ondara, K., Ridwan, N., \& Kusumah, G. (2019). Riset Terintegrasi Kondisi Lingkungan Perairan Situs Kapal Tenggelam SS Aquila di Teluk Ambon Indonesia. Jurnal Kelautan Nasional, 14(1), 1-9.

Ridwan, N. N., Kusumah, G., Husrin, S., \& Altanto, T. (2014). Potensi Wisata Selam Situs Kapal Tenggelam Japanese Cargo Wreck di Pantai Leato Gorontalo. KONAS IX, (pp. II 303-320). Surabaya.

Sari, N. A., Putra, I. N., \& Dirgayusa, I. P. (2017). Kajian Kesesuaian Wisata Selam dan Snorkeling di Perairan Tulamben Karangasem Bali. Journal of Marine and Aquatic Sciences, 3(1), 99-114.

Syahputra, A. A., Yunasfi, \& Suryanti, A. (2016). Analisa Kesesuaian dan Daya Dukung Ekowisata Pantai, Selam dan Snorkeling di Pulau Berhala Kabupaten Serdang Bedagai Provinsi Sumatera Utara.

Yulianda, F. (2007). Ekowisata Bahari Sebagai Alternatif Pemanfaatan Sumberdaya Pesisir Berbasis Konservasi [Makalah]. Bogor. 